\title{
Parental Environment Quality, Mother-Child Attachment, and Cognitive Development of Preschool Children with Working Mother
}

\author{
Saniatu Aini* \\ Department of Family and Consumer Sciences, \\ Faculty of Human Ecology, \\ Bogor Agricultural University \\ Neti Hernawati \\ Department of Family and Consumer Sciences, \\ Faculty of Human Ecology, \\ Bogor Agricultural University \\ *Corresponding author: saniatu@gmail.com
}

\begin{abstract}
This research aimed to analyze parental environment quality, attachment between mother and children, cognitive development, and correlation among those variables. This research took place at Tanah Sareal and Bogor Barat, Bogor City and involved 39 children at preschool age with their mom chosen by purposive method. Data were collected by interview using structure questionnaire and observation. Data were analyzed by descriptive analysis and correlation. More than 50 percent children have the medium score of the parental environment quality, attachment at average category, and cognitive development. Mothers education were correlated significantly positive with parental environment quality, learning, and attachment.
\end{abstract}

Keyword: parental environment quality, learning environment, attachment, cognitive development, working mother, preschool child

\begin{abstract}
Abstrak
Penelitian ini bertujuan untuk menganalisis kualitas lingkungan pengasuhan, kelekatan ibu-anak, perkembangan kognitif anak usia prasekolah, dan korelasi antar variabel penelitian. Penelitian dilakukan di Kecamatan Tanah Sareal dan Kecamatan Bogor Barat, Kota Bogor dan melibatkan 39 anak usia prasekolah beserta ibunya yang dipilih secara purposive. Pengambilan data dilakukan dengan teknik wawancara dan observasi dengan alat bantu kuisioner dan Alat Permainan Edukatif (APE). Data dianalisis dengan analisis deskriptif dan korelasi. Lebih dari separuh anak memiliki kualitas lingkungan pengasuhan terkategori sedang. Kelekatan ibu-anak terkategori pada kelekatan sedang. Perkembangan kognitif terkategori sedang. Lama pendidikan ibu berhubungan positif signifikan dengan kelekatan ibu-anak dan kualitas lingkungan pengasuhan. Kualitas lingkungan pengasuhan berhubungan positif signifikan dengan kelekatan ibu-anak.
\end{abstract}

Kata kunci: kualitas lingkungan pengasuhan, kelekatan ibu-anak, perkembangan kognitif, ibu bekerja, anak usia prasekolah 


\section{Introduction}

Preschool is an ideal time for children to learn specific skills. According to Hurlock (1980) there are three reasons why preschool is an important time for children to learn a variety of things. Firstly, a child has a strong desire to perform various activities repetition of the various activities that he does, so that they are skilled in performing these skills. Secondly, preschoolers have a daredevil nature, so they does not have the barriers of fear when he experiences pain or ridicule of friends. Thirdly, because they have a body that is still very pliable, then they will be very easy and fast to learn a new skill. If at this time the child is not given an opportunity to learn a particular skill, then he will certainly miss to master certain skills that have been first owned by his peers, and he will have less motivation to study a variety of skills when given chance.

Cognitive development of preschool children can not be separated from the family environment, economic resources, and the characteristics of the parents. Previous research stated that the interaction that connected between parent and child, the accuracy of giving stimulus, and a healthy environment have an influence on cognitive development of children (Llras 2008). Therefore, it can be concluded that the quality of parenting environment has a great influence on the child's cognitive development.

ILO data showed an increase in participation rate of working women in Indonesia in the last four years. In 2009, the Working Women's participation rate was 51.0 percent and increased to 53.26 percent in 2013. This phenomenon does not only happen in Indonesia, but also in the other countries, like America. The phenomenon is in line with the statement Bianchi (2000) that there is an increase of Labor Force Participation Rate of women in the United States each year.

The role of women is still synonymous with primary caregivers which are becoming significantly important when they have children of preschool age. According Puspitawati (2012) a woman who runs a dual role as wife, mother, and professional workers would find difficulty in choosing between career and family demands. This is consistent with the opinion of Cudy and Wolf (2013) that working mothers have a greater challenge than the father who worked.

The dependence of children during the preschool years is particularly in terms of secure and happy feeling. According Melhuish (2010) mother-child joint activities will affect the cognitive development of children. The child's cognitive development also related to achievement in school. Therefore, it can be said that the attachment is the main foundation for children's development, particularly cognitive development. The objectives of this study were: 1) to identify the characteristics of families and children, parental environment quality, attachment, and cognitive development of preschool children in families with working mothers; and 2) to analyze the relationship between family characteristics, child characteristics, parental environment quality, and cognitive development of preschoolers. 


\section{Research Method}

Research design of this research used cross sectional study. Locations were selected based on Statistic Center data per year in 2013 which stated that the highest number of children under five year in the city of Bogor is in Tanah Sareal Subdistrict with the total of 15.773 children, and in West Bogor Subistrict is 15.149 children. The research was done in March-August 2015 consisting of preparation, data collection, data processing, data analysis, and report writing.

Population of this study is families with working mothers who have preschool children and live in West Bogor and Tanah Sareal subdistrict. The study was conducted in two selected districts in the city of Bogor, that is, Tanah Sareal and West Bogor subdistrict. Based on data from the Tanah Sareal and West Bogor subdistrict, respondents were purposively selected. The study involved 39 children under five years and their mothers.

The research data were derived from primary data. The primary data were obtained through the instruments that have been tested their realibility. Furthermore, primary data obtained through observation and interviews used Instruments Tools and Educational Games Equipment (APE). The research data which collected including family characteristics (maternal age, family size, length of mother's education, mothers' working hours, and income per capita), the characteristics of the child (gender and age), the parental environment quality were measured by using an instrument of parental environment quality developed by Caldwell and Bradley (1984) in Hastuti (2009). Parental environment quality instruments used were instruments for the category of ages 3 to 6 years consisting of 55 questions with a minimum score of 0 and a maximum score of 55, with a Cronbach's alpha value of 0.832. Instrument of parental environment quality consisted of 8 dimensions of inquiry, namely stimulation of learning, language stimulation, physical environment, warmth and acceptance, academic stimulation, modeling, variations of stimulation in children, and punishment.

Mother-child attachment used Attachment Q-Sort instruments which was developed by the Water and Deane (1985) in Sukardi (2011) with Cronbach's alpha 0.616 consisting of item of explorative behavior, response of affention and social consciousness consisting of 27 items of questions in which secure attachment was given 1 score and insecure attachment was given 0 score. Cognitive development was measured using an instrument developed by the Ministry of Education (2004), by using a cut off low, medium, and high. Data processing was done using Microsoft Excel and SPSS for Windows. Statistical analysis used correlation and descriptive tests.

\section{Result}

Based on the BKKBN, large families are divided into three categories, namely small families, medium families, and large families. The results showed that most of the sample $(89.7 \%)$ belongs to small families ( $\leq 4$ people). 41.03 percent of women have secondary education. Based on the poverty line Bogor City (2013) the average income per capita per month was not considered poor in the amount of USD 360518 . The results showed that more than half the sample (69.2\%) was categorized not poor with an average per capita income of Rp 1,138,804. Age of the mother was in the range 23-42 
years, with an average age of 31.03 years. Mothers' working hours are in the range 2.516.5 hours per day, with an average length of working mothers for 9 hours per day. 41.0 percent of mothers worked as an employee.

\section{Child Characteristic}

Children in this study were 39 people which consisted of 19 boys $(48.7 \%)$ and as many as 20 people were girls $(51.3 \%)$. The age range of children are at the age of 3 years to 5.9 years with an average age of 4.3 years.

\section{Parental environment quality}

Parental environment quality is parenting measurement parameters that associated with parenting stimulation provided by parents and families. Measurement parameter of parental environment quality consists of eight dimensions: learning stimulation, language stimulation, physical environment, warmth and acceptance, academic stimulation, modeling, variations of stimulation to the child, and punishment. The instrument used to measure the environmentparenting quality in this study is an instrument developed by Caldwell and Bradley (1984). The instruments of parenting enviroment quality measurement were designed to describe the stimulation and responsiveness of mother, maternal involvement and acceptance of the mother for her child, the availability of materials that support the development of children's learning, and variation of environmentparenting (Huston \& Aronson 2005) (Table 1).

\section{Mother-Child Attachment}

Attachment is a strong psychological connection that connects between mother and child. The better attachment that exists between mother and child, the more positive the emotional relationship between the child with the environment and the people around him.

Table 1 The average value, the maximum-minimum child based on the dimensions of parental environment quality

\begin{tabular}{lcc}
\hline \multicolumn{1}{c}{ Dimensions } & Min-Max & Mean \pm SD \\
\hline Learning Stimulation & $27.0-100.0$ & $66.0 \pm 20.0$ \\
Language Stimulation & $29.0-100.0$ & $95.0 \pm 13.0$ \\
Physical Environment & $14.0-100.0$ & $68.0 \pm 32.0$ \\
Warmth and Acceptance & $0.0-100.0$ & $68.0 \pm 28.0$ \\
Academic Stimulation & $0.0-100.0$ & $51.0 \pm 12.0$ \\
Modelling & $0.0-100.0$ & $64.0 \pm 32.0$ \\
Varition of stimulation to child & $33.0-100.0$ & $74.0 \pm 16.0$ \\
Punishment & $0.0-100.0$ & $85.0 \pm 22.0$ \\
\hline \multicolumn{1}{c}{ Total } & $41.8-94.5$ & $74.6 \pm 12.8$ \\
\hline
\end{tabular}

Based on the dimensions, the mother-child attachment is divided into three, that are explorative behavior, the response of affection, and social awareness. Based on the three dimensions, the dimension of the affection response is a dimension which has the 
highest average score (72.0) than that in the social consciousness (68.9) and that in explorative behavior (58.0).

Table 2 Mean Value, minimum-maximum based on the dimensions of the motherchild attachment

\begin{tabular}{|c|c|c|}
\hline Attachment Dimension & Min-max & Mean \pm SD \\
\hline Explorative Behavior & $12.5-100.0$ & $58.0 \pm 23.6$ \\
\hline Respon of Affection & $50.0-90.0$ & $72.0 \pm 13.0$ \\
\hline Social Awareness & $33.3-100.0$ & $68.9 \pm 18.1$ \\
\hline Total & $12.5-100.0$ & $67.0 \pm 12.4$ \\
\hline
\end{tabular}

Based on this research, the child that is in the category of medium attachment (46.2\%), 35.9 percent of children were categorized into a low attchment with his mother, and 17.9 percent of children were categorized into secure attachment with his mother.

Table 3 Distribution of children by attachment category

\begin{tabular}{lccc}
\hline & Attachment Category & $\mathrm{n}$ & $\%$ \\
\hline Low & & 14 & 35.9 \\
Medium & & 18 & 46.2 \\
High & & 7 & 17.9 \\
\hline \multicolumn{2}{c}{ Total } & 39 & 100.0 \\
\hline & Min-max & \multicolumn{2}{c}{$52.6-94.7$} \\
\hline
\end{tabular}

\section{Cognitive Development}

The achievement average of cognitive development of preschool children in this study was in the category of middle (43.6\%), high (41.0\%), and low (15.4\%). Research showed that there were six children categorized into low cognitive development. There were some supporting reasons why the children were categorized into lower cognitive development. This was due to a low maternal education. There is one respondent who had a mother with a 2 year study period. Low of maternal education is directly proportional to lower cognitive development of children. This is consistent with research Llras (2008), that the lower the education of a mother, the lower the cognitive development of children will be (Table 4).

Table 4 Distribution of children by category of cognitive development

\begin{tabular}{|c|c|c|}
\hline Category of Cognitive Development & $\mathrm{n}$ & $\%$ \\
\hline Low & 6 & 15.4 \\
\hline Medium & 17 & 43.6 \\
\hline High & 16 & 41.0 \\
\hline Total & 39 & 100.0 \\
\hline Minimum-Maximum & \multicolumn{2}{|c|}{$42.3-100.0$} \\
\hline Mean \pm SD & \multicolumn{2}{|c|}{$75.9 \pm 14.8$} \\
\hline
\end{tabular}

The analysis showed that children who were in low category of parental environment quality have moderate cognitive development $(2.6 \%)$ and high-category of cognitive development $(2.6 \%)$. As for children who have moderate parenting enviroment quality have moderate cognitive development (30.8\%) and high $(23.1 \%)$. Children who have high- parenting enviroment quality have high cognitive development 
(15.4\%) and moderate cognitive development (10.3\%). Overall, percentage of children who have the parental environment quality consists of a lower $(15.4 \%)$; moderate $(43.6 \%)$; and high category $(41.0 \%)$.

Based on the research, children who have a high attachment with his mother have the medium cognitive development $(20.5 \%)$, as well as with children who have medium attachment with a mother who was also categorized on medium cognitive development $(17.9 \%)$. Meanwhile, children whose attachment were categorized in the low attachment have the same percentage on the cognitive development of low and medium category that is equal to 7.7 percent (Table 6).

\section{Relationship Among Characteristics of Children, Families, Mother-Child Attachment, Dimension of Parental environment quality and Cognitive Development}

Results of correlation test between the characteristics of the children, family, mother-child attachment, parental environment quality dimension, and cognitive development resulted in several important points, that is, length of maternal education is significantly positively associated with the parental environment quality $(r=0377, p$ $<0.05)$. This shows that the longer a mother's education, the better the parental environment quality will be. Length of mother's education is also significantly positively associated with attachment $(\mathrm{r}=0.3851$; $\mathrm{P}<0.05)$. This shows that the longer a mother's education, the more secure attachment that connected between mother and child will be.

Table 5 Relationship of family characteristics, child characteristics, parental environment quality, attachment, and cognitive development

\begin{tabular}{lccc}
\hline \multicolumn{1}{c}{ Variable } & $\begin{array}{c}\text { Parental environment } \\
\text { quality }\end{array}$ & Attachment & $\begin{array}{c}\text { Cognitive } \\
\text { Development }\end{array}$ \\
\hline Characteristic of Familiy & -0.037 & 0.074 & 0.095 \\
Maternal Age & 0.061 & -0.126 & -0.139 \\
Large Families & $0.327^{*}$ & $0.3851^{*}$ & 0.251 \\
Length of Mother Education & -0.117 & 0.106 & -0.138 \\
Income pe r capita & 0.077 & 0.280 & -0.057 \\
Work Hour of Mother & & -0.041 & -0.231 \\
Characteristic of Children & 0.104 & $0.410^{* *}$ & -0.014 \\
Usia Anak & 1.000 & 1.000 & 0.196 \\
EnvironmentParenting Quality & $0.410^{* *}$ & 0.196 & 1.000 \\
Attachment & -0.014 & & \\
Cognitive Development & &
\end{tabular}

Explanation : ${ }^{*}=$ significant at $\alpha=0.05$

Research of Ara (2012) states that the longer a mother's education work, the more facilities to support the development of children they can give to optimalize the development. Similarly with the attachment, the longer education, the more sensitive parenting to their children will be. Therefore, attachment that connects between mother and child will be more secure. The correlation test results showed that the characteristics of the family and characteristic of child is not significantly correlated with cognitive development. 


\section{Discussion}

Parental environment quality is related to parent-child interaction, the quality of the home environment, and measurement of the child's appearance (Hastuti 2009). Besides that, Parental environment quality also consists of a series of measurements of the quality and quantity of stimulus, either material or psychological nature which exists at home for children, (Totsika \& Sylva 2004).

Parental environment quality is generally categorized into three, namely: low, medium, and high. Classification of all three categories, according to size of achievement scores on the accumulation of scoring of the 8th dimension measurements. The higher score obtained, the higher stimulus to the child whether it is psychological stimulus or stimuli that have material characteristic. 48.7 percent of children have a medium parenting environemtn quality. Meanwhile, 38.5 percent of children have a high parental environment quality and 12.8 percent of children have a low parental environment quality.

Based on the research conducted, the higher of mother's education, the better parental environment quality held by a subsidiary. Length of mother's education is directly proportional to the amount of mother's income, so the higher income mothers have, the better access to services or facilities that can support a child's development (Nelen, Grip \& Fourage 2013). Meanwhile, according to Bianchi (2011) the more intellectual of a mother, the more optimal stimulus and the better parenting environment which can be provided to support children's development. Intellectual level of a mother is related to understanding and the ability to access to information, as well as books and the internet.

Attachment is a close emotional bond between two people (Hurlock 1980). If interpreted in the mother-child relationship, the attachment is a close emotional bond between child and caregiver that is ever lasting (Santrock 2003). Attachment that exists between mother-child as the primary caregiver is eternal because the attachment is one of the determinants of the quality of the relationship between children and parents (Bowlby 1985; Malekpour 2011).

Based on the results of the study, the average score of the mother-child attachment in this study is 66.9 and the middle category (46.2\%). Although a mother works, she still can establish a good attachment with their children. This is consistent with the research Huston and Aronson (2005) that there was no difference between attachment at the mother who works and does not work. Working mother made him enable to optimize the quality of the time that he had with his son, especially in terms of interaction. This is apparent from the research conducted, that the dimensions of the measurement of the response of affection between mother-child attachment obtain a high percentage of 100 percent. This response of affection is a manifestation of the outpouring of concern and affection towards his mother although in this research, there is still a child who has a lower attachment of 35.9 percent. This is not inseparable with the mother's education, long working mothers, as well as the economic status of the family.

According to Malekpour (2007), positive or negative attachment that connects between parent-child gives influence the brain structure in children's development. 
When the attachment connecting between mother-child is good, it makes child's cognitive development better. Cognitive development is a growth of how a child learns through his actions involving the process of assimilation and accommodation. Preschoolers are at pre-operational stage which at this stage the child' ability to think about an object, event or other people begins to grow. Children begin to recognize symbols to represent objects in the vicinity, but at this stage the children's way of thinking relies on concrete objects, the present time span, and the place where they are (Piaget \& Inhelder 2000).

Research shows that 43.6 percent of children are in the medium category of cognitive development with average value of cognitive development 75.9. Based on the distribution of cognitive development, boys $(25.6 \%)$ are more superior than girls $(15.4 \%)$. This is consistent with the Hurlock (1980) that there is a difference between the mastery of skills boys and girls in early childhood.

Scores achievement of cognitive development was associated with gender and duration of working mothers. Based on the research, overall outcomes of cognitive development of children were categorized as medium (43.6\%); cognitive development of boys are superior $(25.6 \%)$ than that of girls $(15.4 \%)$; and 23.1 percent of children whose mothers work less than 8 hours per day were categorized into superior cognitive development than children whose mother work more than equal to 8 hours per day $(20.5 \%)$.

Limitations of this study include the number of respondents and the limited research time; therefore, the results and conclusions in this study have not been fully able to describe the expected results.

\section{Conclusion and Suggestion}

\section{Conclusion}

The results showed that the parental environment quality is in the middle category (49.0). The achievement of high category is on the dimensions of language stimulation $(92.0 \%)$, while the dimensions which are still in the low category are the dimension of academic stimulation (41.0\%). The results showed that the mother-child attachment is in middle category (56.4\%), with the average score of 67.0 overall attachment. The mean score of the achievement of the cognitive development of preschool children is more superior in the group of children aged 30-41 months (83.8) with the average achievement scores of cognitive development of $75.9 \%$. Overall, the achievements of cognitive development of children in the study were in the middle category (43.6\%).

Based on the research conducted, the longer the mother's education, the better the parental environment quality and the better attachment among the youngs and their mothers. Similarly, with the parental environment quality, the better enviromental parenting quality, the better attachment that exists between a mother and a child. Meanwhile, cognitive development does not have a significant relationship with the various dimensions examined 


\section{Suggestion}

Based on research conducted, a mother should be, especially working mother is more responsive to gender-based parenting, for example women often invites his son to talk more, let his son free to express the emotions that he felt (not suppress emotion), and did not immediately stop physical contact early age in order to build a better attachment between mother and her son. To optimize the environmentparenting quality, parents should be able to actively provide academic stimulus to their children, in order to create a learning environment that can optimize cognitive development of children. In addition, parents should involve their children in early childhood education program to optimize the stimulus which can improve cognitive development of children. Furthermore, mothers should pay attention to working hours, so that the mothers can provide a more optimal cognitive stimulus in children. For further research, there should be a collaboration between science studies families and other child development to measure the development of preschool children in families with working mothers.

\section{Reference}

[AIMH] (UK) The Association for Infant Mental Health (UK), The Child Psychotherapy Trust. 1999. Promoting infant mental health: a framework for developing policies and services to ensure the healthy development of young children.

[ILO] International Labour Organization. 2013. Labour and Social Trends in Indonesia: Strengthening the Role of Decent Work in Growth Equity. International Labour Organization.

Ara N. 2012. Educated working mothers to hoist children academic performance, 1 (2).

Bowlby J. 1958. The nature of the child's tie to his mother. International Journal of Psycho-Analysis.

Caplan T, Caplan F. 1983. The Early Childhood Years: The 2-6 Year Old. Toronto-New York-London-Sydney-Aucland: Bantam Books.

Cudy AC, Wolf EB. 2013. Presciptions and punishment for working moms: how race and work status affect judgement of mothers [penelitian].

Gender And Work : Challenging Conventional Wisdom. Harvard Business School.

Hastuti D. 2009. Care: Theory and Principles And Its Application in Indonesia. Bogor (ID): Department of Family and Consumer Sciences.

Hurlock E. 1980. Developmental Psychology; Istiwidayanti, Soedjarwo, translator; Sijabat RM, editor. Jakarta (ID): publisher. Translation from: Developmental Psycology: A Life-Span Approach. 5th ed.

Huston AC, Aronson SR. 2005. Mothers' time with infant and time in employment as predictors of mother-child relationship and childrens' early development. Child Development. 2 (76).

Lleras C. 2008. Employment, work conditions, and the home environment in singlemother families. Journal of Family Issues. DOI: 10.1177/0192513X08318842.

Malekpour M. 2007. Effect of attachment on early a development. The British of Development Disabilities, 105 (53). 
Melhuish E. 2010. Imact Of The Home Learning Environment On Child Cogntive Development: Secondary Anaysis Of Data From Growing Up In Scoutland. Scoutland: Scottish Goverment Social Research.

Nelen AK, Grip A, Fouarge D. 2013. The relation between maternal work hours and cognitive outcomes of young school-aged children. Discussion Paper. No 7310.

Piaget J. Inhelder B. 2000.The Psychology of the Child; Weaver H, translator; Kagan J, editor. New York (USA) : Basic Book. Translation of : La Psychologie de I'enfant.

Puspitawati H. 2012. Gender and Family: Concept and Reality in Indonesia. Bogor (ID): IPB Press.

Quinn PJ. Caallaghan MO, Williams G, Najman JM, Andersen MJ, Bor W. 2001. The effect of breastfeeding on child development at 5 years: A Cohort Study. Journal Of Pediartrics And Child Health. 5 (37). DOI 10.1046/j.1440-1754.2001.00702.x.

Santrock JW. 2003. Developmental Psychology: Adolescene Youth Development, Saragih S, a translator; C Vishnu, editor; B Shinto, editor. Jakarta (ID): publisher. Translation of: Adolescence.

Sukardi AN. 2011. Study history of child development, sensitivity, and the attachment of mothers towards children aged 3-5tahun in indigenous villages urug Bogor regency. [Thesis] Bogor [ID]: Faculty of human ecology. Bogor Agricultural Institute.

Totsika V, Sylva K. 2004. The home observtion for measurment of the environment revisited. Child and Adolecent Mental Health. 9 (1). 